original type cultures were unavailable. The procedure for proposing and validating neotypes was also considered. The median organism and the centrotype concepts are here suitable, but although they serve to describe the centre of phenetic clusters they have less power to define their borders, and various suggestions were made on how this might be done.

The conference then went on to discuss the kinds of information which can be obtained from biochemical tests and to the problem of standardizing them. This latter problem is a difficult one, and Prof. V. B. D. Skerman (University of Queensland, Brisbane) introduced this. Discussion on this was rather inconclusive, and it is evident that a huge task faces microbiologists if they are to bring order into the field. There seemed to be a general feeling that test methods for each major group of bacteria would need standardizing for that group, but the problem of reliable comparisons between major groups was more difficult. Several speakers emphasized that descriptive taxonomic tests required different treatment from rapid diagnostic tests for identification; the latter were best devised after sound taxa had been established on the basis of the former, and diagnostic tests could and should be devised for their own special purposes. Dr. O. Lysenko (Institute of Biology, Prague) also made a plea for some standardization in the descriptions of bacteria (as is now being considered in the A.ctinomycetes), which would avoid many of the present difficulties due to inadequate descriptions in taxonomic studies.

Prof. J. De Ley (State University, Ghent) went on to describe the comparative biochemistry of micro-organisms, and pointed out that there are large areas that were untapped for taxonomic work, either because the comparative biochemistry was not yet known, or because the techniques were not familiar to most microbiologists.

Dr. Rita R. Colwell (Georgetown University, Washing. ton, D.C.) and Dr. R. Hugh (George Washington University, Washington, D.C.) described the practical organization of a laboratory for taxonomic studies. They were followed by Prof. O. B. Weeks (University of Idaho, Moscow, Idaho) and Dr. Muriel E. Rhodes (University College of Wales, Aberystwyth), who illustrated the theme with two particular examples-pigment and flagella respectively. Dr. L. Colobert (Centre de Recherches du CRSSA, Lyon) demonstrated a handy device for rapid testing.

The next session dealt with modern data-processing machines, lucidly described by Dr. F. J. Rohlf. Prof. Skerman discussed the setting-up of a world data centre for bacteriology, and Dr. C. Quadling (Biosciences Division, National Research Council, Ottawa) gave details of the punched-card system being introduced by the
Canadian Committee on Culture Collections. Merging with this was a session on identification and how dataprocessing equipment can assist. Dr. K. J. Steel (National Collection of Type Cultures, Colindale, London, N.W.9) reviewed the prospects here, and described the wide range of identification techniques that are now available. Papers were read on behalf of Dr. L. C. Payne and Mr. D. A. Franklin (Elliott Medical Automation, Boreham Wood, Herts.) and Dr. W. Dybowski (Medical Laboratory Centre, Eastcote, Middlesex) describing a computer system that-from the test results on an unknown organism and the accumulated knowledge of bacteria stored in the computer memory - will print out the most likely alternatives together with any new tests that may be needed for confirmation of the identification. Several speakers touched on the central role of computers in the future, whether on-line in hospitals and laboratories for swift diagnosis, or handling the output of the automated testing machines that are being planned, or in the numerical taxonomy of micro-organisms and the production of diagnostic keys and tables for those without ready access to computers. The logical necessity for constructing classification before identification schemes was also emphasized.

The contribution of genetics and molecular biology to taxonomy was a particularly interesting topic, provoking much lively discussion. It was introduced by Dr. M. Mandel (Anderson Hospital, Houston, Texas). He showed how $G C$ base ratios of DNA could contribute toward deciding if major groups were homogeneous and could also indicate possible taxonomic affinities; he went on to discuss the practical difficulties of work on nucleic acid homology by base pairing - a field which potentially has great possibilities in taxonomy by revealing fine genetic homology. Dr. Colwell, Prof. De Loy and Dr. Lily Jones (University of Minnosota, Minneapolis) described their recent findings in the field, and an interesting point that emerged was that strains that are phenetically typical of a cluster were also, as far as present experience goes, typical in $G C$ content.

The conference ended with a session led by Prof. M. P. Starr (University of California, Davis) and Prof. Liston, in which participants from different disciplines summed up their reactions, and consideration was given to the future support of work in microbial classification. There was enthusiasm for arranging a second such conference in a few years' time. The proceedings of the present meeting will not be published in full; but it is hoped that the original work presented will be published in the appropriate journals. The conference was supported by the National Research Council of Canada, the U.S. National Science Foundation and the A.merican Society for Microbiology.

\title{
OBITUARY
}

\section{Dr. Eric W. Buxton}

ERIo Buxton's friends the world over will be grieved to learn of his death at Harpenden on August 4, 1964 , at the age of thirty-eight years. His illness, which lasted for over a year, cut short a brilliant career in plant pathology.

Eric William Buxton was born at Ripley in Derbyshire on June 9, 1926. He joined the Royal Air Force in 1944. In 1948 he went up to Cambridge where he gained a double first in the Natural Science Tripos, specializing in botany. He was awarded the Aldis scholarship at Trinity Hall in 1950, and later held a College research scholarship and an Agricultural Research Council studentship, during the tenure of which he worked at the Botany School under the supervision of Dr. (now Professor) Noel F. Robertson, with a 6-month interlude while he studied in Glasgow under Prof. G. Pontecorvo. These experiences expanded his early work on diseases of Gladiolus into the wider problems of pathogenicity and genetics of tho genus Fusarium. In 1954 he came to the Plant Pathology Department at Rothamsted Experimental Station, and rapidly gained international esteem for the new ideas he brought to the study of plant pathogenic fungi in the soil. By pairing avirulent mutants, produced by ultra-violet irradiation of virulent isolates of Fusarium from wilted peas, he obtained heterokaryons that were as virulent as the wild-type, and he suggested that such heterokaryons might arise naturally in the soil before invasion of a host plant, thus forming, from originally non-pathogenic clones, pathogenic heterokaryons that would break up again when the fungus sporulated on dead host tissue and so might escape detection. Further, he showed that 
nutritionally deficient mutants can attack resistant varieties of host if the appropriate nutrient is supplied with the inoculum.

Parasexual recombinations within heterokaryons of pea-wilt and banana-wilt Fusaria were indicated as one source of variability. The terminal cell in Fusarium was shown to be multinucleate and therefore potentially heterokaryotic, and Buxton suggested that a few pathogenic nuclei might survive in heterokaryons containing predominantly nuclei adapted to saprophytic existence in mycelia growing saprophytically in soil. Avirulent mycelia could thus constitute a reservoir from which pathogenic forms, with mainly pathogenic nuclei, could arise when selectively favoured by the proximity of a host plant. Buxton's work on pea-wilt threw important light on the mechanisms of resistance and susceptibility of plant to fungus by showing that exudates from roots of one variety of pea can inhibit growth of a race of Fusarium oxysporum f. pisi to which that variety is resistant, but stimulate another race to which it is susceptible. Further, he showed that when conidia of race-I were held for 14 days in concentrated root exudates from a host plant resistant to race-1, some were modified into race-2 pathogenicity. Genetic variability was Buxton's prime interest, but he was no narrow specialist; his 40 publications show his unusual versatility, as he was equally able and productive in practical work on disease control as in more academic studies. He also served as Secretary to the British Mycological Society's Plant Pathology Committee, and was on the Editorial Board of the Journal of General Microbiology.

With the award of a Kellogg Foundation fellowship, Buxton made his first visit to the United States in 1957. In 1958 he returned as the guest of the American Phytopathological Society to contribute to their golden jubilee meetings at Bloomington, Indiana, and in 1960 he went at the invitation of the United Fruit Co. to work for a year in their laboratories at Norwood, Mass., on Fusarium wilt of the banana.

His stimulating conversation, his ability to teach and his friendly personality explain why Buxton's laboratory was sought, not only by his colleagues, but also by visitors from other parts of the world. In 1950 he married Doreen Hampson of Ripley, Derbyshire, who survives him with their three sons. He gave to his family life the same zest as his research.

P. H. Gregory

\section{NEWS and VIEWS}

\section{Directorship of the Commonwealth Mycological}

Institute:

Dr. J. C. F. Hopkins, C.M.G.

Dr. J. C. F. Hopkins, who retired on September 30 from the directorship of the Commonwealth Mycological Institute, Kew, a position he had held since 1956 (Nature, $178,1150 ; 1956)$, is well known as a versatile tropical plant pathologist. After service in the Royal Air Force during the First World War, he graduated from the University of London and continued his training in Trinidad at the Imperial College of Tropical Agriculture. For the next two years he worked in Uganda, then moved to Southern Rhodesia, where in the course of twenty-cight years he was successively mycologist, senior plant path ologist, and finally chief botanist and plant pathologist. An authority on diseases of tobacco in Africa, and the author of the standard book on this subject, Dr. Hopkins's services have been in much demand, and during recent years he has travelled widely both as a consultant and on behalf of his Institute and the Commonwealth Agricultural Bureaux. Under his directorship, in addition to a general expansion of the work of the Institute, a unit for the identification of plant pathogenic bacteria was successfully initiated. Dr. Hopkins has taken an active interest in the affairs of the Institute of Biology and besides serving on the Council has acted as chairman of the London Branch. In 1962, in recognition of his public services, Dr. Hopkins was appointed a Companion of the Order of St. Michael and St. George.

Dr. G. C. Ainsworth

Dr. G. C. AInsworth, who has been appointed to sueceed Dr. J. C. F. Hopkins as director of the Commonwealth Mycological Institute, obtained a London firstclass honours degree in botany in 1930 and was awarded a Ph.D. in 1934. He showed an early interest in medicine, obtaining a Ph.C. in 1929 and was awarded the Pharmaceutical Society's silver medal and the Harrison Memorial Prize. From 1930 until 1939 he studied plant diseases at Rothamsted and Cheshunt, where he specialized in crop diseases, particularly those due to viruses. He was then appointed to the Commonwealth Mycological Institute and helped in the production of the Review of Applied Mycology; he also prepared a monograph on the British Ustilaginales. After the Second World War, his earlier interests became evident again and he was appointed head of the Mycological Department at the Wellcome Research
Laboratories working on antibiotics and developed research on the mycoses of man and animals. As a natural consequenco, he was soon appointed a Wellcome Trustees Research Fellow in medical mycology at the London School of Hygiene and Tropical Medicine, and his insistence on accurate identification and correct nomenclature from that time onwards has had a marked effect on the development of this discipline, especially under the sponsorship of the Mycology Committee of the Medical Research Council, of which he was secretary for ten years. In 1948, he was appointed lecturer in botany at the University College of the South West of England (now University of Exeter), and was promoted reader in 1951. Ho continued his researches into the mycoses of animals, and the records of a two-yoar survey, supported by the Agricultural Research Council, of mycotic diseases of farm animals in Britain were transferred to the Central Research Laboratory, Weybridge, as the basis for a new veterinary mycology unit. But the call of the Commonwealth Mycological Institute proved too strong and he returned there to be made, in 1961, assistant director. $\mathrm{He}$ has been president of the British Mycological Society, but is probably best known throughout the world as the author of The Dictionary of the Fungi, the fifth edition of which has recently been published.

\section{Registrar and Secretary to the Council for National Academic Awards: Mr. F. R. Hornby, M.B.E.}

MR. F. R. HoRnBy has been appointed registrar and secretary to the Council for National Academic Awards. Mr. Hornby was educated at Heversham Grammar School, Westmorland, and Magdalene College, Cambridge, where he obtained first-class honours in the Natural Science Tripos, Parts I and II. He has taught in Highbury County Secondary School, London, and at Taunton School, Somerset. During the Second World War he served with the Royal Army Ordnance Corps and the Royal Army Education Corps, and attained the rank of Lt.-Colonel and was awarded an M.B.E. for services in North Africa and Italy. Bofore he became secretary of the National Council for Technological Awards in 1956 he was assistant education officer in the City of Notting. ham Local Education Authority.

The charter and statutes of the new Council for National Academic Awards were published on September 25, and 